\title{
Machu Picchu-The Sublime Stone Citadel
}

\author{
Shala Lin* \\ Phillips Academy Andover, Massachusetts, USA
}

*Corresponding author: Shala Lin, Phillips Academy Andover, Massachusetts, USA.

Received Date: November 27, 2019

Published Date: January 06, 2020

\section{Introduction}

Tucked away in the mountainous countryside just north of the Incan capital, Cusco, lies Machu Picchu. Wiped out by the Spanish invaders in the $16^{\text {th }}$ century, Machu Picchu became merely a forgotten citadel. For hundreds of years, its existence was only known by a few livings in the region. However, in 1911, Hiram Bingham III, with the backing of Yale University, led a group down the Urubamba River to search for the last capital of the Inca. An explorer and historian, Bingham had already traveled in the Andes previously, even having reached Choquequirao, a site to the south of Machu Picchu [1]. With the help of his military escort and a local farmer, Bingham "discovered" the hidden city in the clouds. The farmer called the mountain Machu Picchu, which meant "Old Peak" in the native Quechua language [2].

Although Bingham brought this spectacular citadel to the attention of the public, documents from the 1550s and 1700s show how some were already aware of the ruins before 1911 [3]. Many archeologists believe Machu Picchu, often referred to as the "Lost City of the Incas" was once constructed as an estate for the Inca emperor Pachacuti Yupanqui and his successors. Though it was considered to be a "royal" estate, Machu Picchu was not passed down in a line of succession. Instead, it was used for 80 years before being abandoned due to the Spanish Conquests in other parts of the Inca Empire. To this day, Machu Picchu is still the best-known archaeological site in South America. Machu Picchu is located in one of the most spectacular settings in the Andes, set amidst lush tropical vegetation on a ridge overlooking a winding river hundreds of meters below and with views toward snowcapped mountains [4]. However, it is not only its location that makes it extraordinary. As a whole, Machu Picchu epitomizes the Inca Empires' success through its display of extraordinary craft, integration to the cosmos, and ability to convert their surroundings into food.

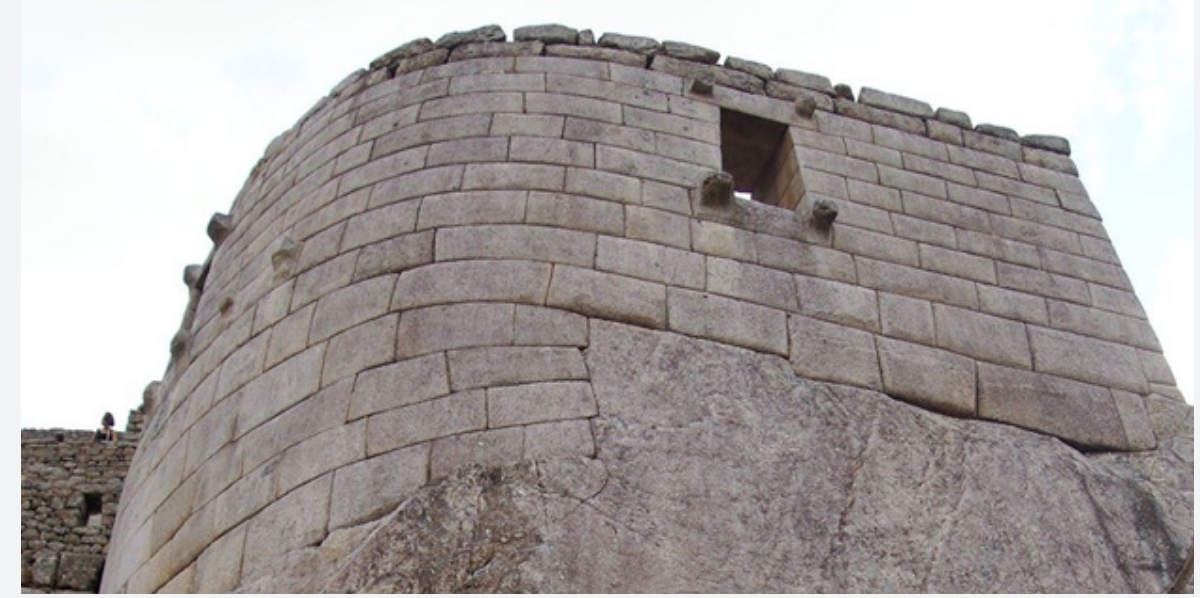

Figure 1: The Round Walls of the Temple of the Sun in Machu Picchu, Photograph, June 19, 2017, Digital File. 
One of the keys defining characteristics of the Inca empire is the finely worked stone structures. When Hiram Bingham III stumbled across Machu Picchu in 1911, he was astounded by the "finest quality of Inca stonework" [5]. Although it was difficult to see, "for [the stones] were partly covered with trees and moss, the growth of centuries... hiding in bamboo thickets and tangled vines, appeared here and there walls of white granite ashlars carefully cut and exquisitely fitted together" [6]. As Bingham and his team continued to scout the area, they stumbled upon, "a cave beautifully lined with the finest cut stone. It had evidently been a royal mausoleum... the [Temple of the Sun] followed the natural curvature of the rock and was keyed to it by one of the finest examples of masonry I had ever seen Figure 1 Furthermore it was tied into another beautiful wall, made of very carefully matched ashlar of pure white granite, especially selected for its fine grain. Clearly, it was the work of a master artist" [7]. He soon realized that "this wall and its adjoining semicircular temple over the cave were as fine as the finest stonework in the world. It fairly took [his] breath away" [8].

Unlike any other ancient civilization, the Incas displayed extraordinary craft and ability to control the rough terrain of the Andes mountains. They had a special relationship to stone, with it being key to their empire-building success [9]. With every stone carved in uniform exactly like the one before, Inca buildings were very pleasing to the eye. The Incas used three different types of stone: Yucay limestone, green Sacsayhuaman diorite porphyry, and black andesite. These stones often weighed many tons-up to more than 100 tons- and required as many as 1,800 laborers [10]. Because the Incas had lacked strong animals- they only had llamas, alpacas, and guinea pigs- they did not use wheels, however, they incorporated that principle when bringing the stones uphill. Blocks were moved using ropes, logs, poles, levers, ramps, and simply by just pushing [11].

Since steel and other hard metals were unknown to the Incas, they used stone, bronze or copper tools. In trying to preserve the natural aspects of the stones, the Incas wedged smaller rocks in between the existing cracks and crevices of larger ones, usually splitting the stones along the natural fracture lines. Judging from tool marks left on the stones it is most probable that the Incas pounded the stones into shape and sanded them off using finer rocks and sand [12]. Another astonishing aspect of the Inca masonry was their ability to precisely piece blocks together without the use of mortar (Figure 2). As Hiram writes in his book, Lost City of the Incas, due to the "absence of mortar, there were no ugly spaces between the rocks. They might have grown together... [Machu Picchu] surpassed in attractiveness the best Inca walls in Cuzco" [13].

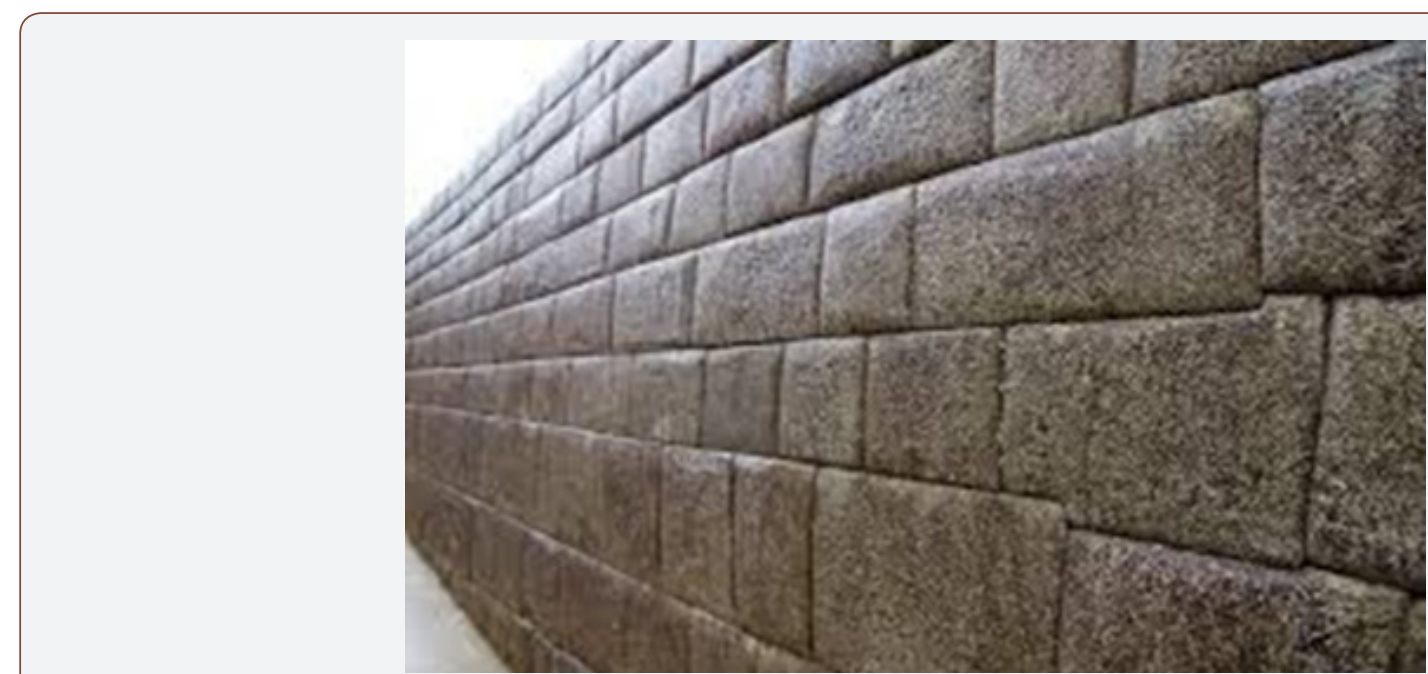

Figure 2: Inca Masonry without Mortar, Photograph, June 19, 2017, Digital File.

The meticulous process of cutting, laying, removing, adjusting, re-cutting, and re-laying blocks so they fit exactly together was a time-consuming project; researchers believed that just to produce a single wall could take up to many months [14]. However, this process was worth it in the end. Earthquakes were frequent because the Inca empire lied on the Andes mountain fault line. In particular, Machu Picchu "sits atop not one but two fault lines" [15]. The interlocking blocks were a crucial reason for why the Inca buildings did not come crumbling down but instead were extremely resistant to the number of earthquakes that have happened over the past 500 years [16].

Another feature of the Inca architecture is that it is typically incorporated the landscape, blending in and blurring the line between natural and manmade. The Inca architects were able to adapt to whatever terrain they were placed in-- always with the common theme of building into their surroundings and preserving it to the best of their ability just how they found it. Through the Incas astounding ingenuity and ability to adapt to their surroundings, they were able to turn stones from the Andes mountains into earthquake-proof structures by hand and without the use of mortar. The masonry also played an essential role in the construction of all religious temples at Machu Picchu. The accuracy and precision of each one of the stones and their placement was a key characteristic that distinguishes it from any other architecture of the time. As Hiram Bingham described Machu Picchu, he had never found anything, "just like it in design... the [Temple of the 
Sun] followed the natural curvature of the rock and was keyed to it by one of the finest examples of masonry I had ever seen" [17].

In the early $15^{\text {th }}$ century, Pachacuti Inca Yupanqui, the ninth Inca ruler, had ambitions to expand the Inca empire throughout South America- stretching from Cusco into Bolivia, Chile, Argentina, and north through Peru, Ecuador, and Columbia [18]. Before the expansion of the Inca Empire, the idea of worshipping the sun, moon, stars, and planets were amongst ancient Andean communities and passed onto the Incas, however it was Pachacuti Inca Yupanqui who formalized and established the cultural practices of the Inca. He incorporated the worship of the Sun god into the religions of the conquered people [19]. The conquered did not have to give up their religion, but simply accept and acknowledge the superiority of Inti [20]. The Incas believed they were direct descendants of the most important god, Inti-the god of the Sun. Their descent from Inti was used to justify their success in conquering their neighboring people and expanding their empire [21]. Pachacuti ordered temples worshipping the Sun to be built all over the conquered land. These projects required major construction and engineering as they were used to embody the importance and power of the Inca. These temples were not only built to worship the Sun god but also to integrate Machu Picchu and the rest of the Inca empire with the cosmos.

When Hiram Bingham III first discovered Machu Picchu, he was starstruck by the temples there. He describes the sight as, “... the finest and most interesting structures in ancient America... The sight had [him] spellbound" [22]. Among these temples was the Torreón which was built in Machu Picchu. In his book, Lost City of the Incas, Bingham describes Torreón, "containing... great windows looking out over the canyon to the rising sun... it is unique among Inca ruins. Nothing just like [it] in design and execution has ever been found" [23]. Since Machu Picchu was specifically built for Pachacuti Inca Yupanqui, he had planned out the community, unlike other cities throughout the empire that evolved over time. It includes all the temples and additional features that Pachacuti designed merely for Machu Picchu. The research of the Torreón and other temples at Machu Picchu has shown that the Incas were capable of precise observations and could have defined the exact dates not only of astronomical events but also the days leading up to them [24].

The Torreón was constructed on a large rock with a clear view of the east. The walls had the finest stonework with one wall curving inward to conform to the shape of the rock foundation and two windows facing northeast and southeast (Figure 3). The Torreón was unique to Machu Picchu with pegs projecting from the exterior of the curved wall and an irregular platform carved in the interior of the structure. Similar to the other Sun temples found throughout the empire, Torreón's northeastern window aligned to a declination of $+21.6( \pm 0.6)$ degrees. However, another feature that made Torreón unique was the straight edge cut into the bedrock platform pointed at a slight angle. This slight angle was oriented previously to the rising point of the Sun during the June solstice [25]. The view out of the southeast window includes several different Inca constellations, for example, the tail of Scorpio. However, the sun could never be seen straight out of this window. The southeast window also had pegs at the four corners. By examining both windows in full range, researchers found that they intersected for about four degrees of horizon. The southeast window was used for determining the zenith passage date.

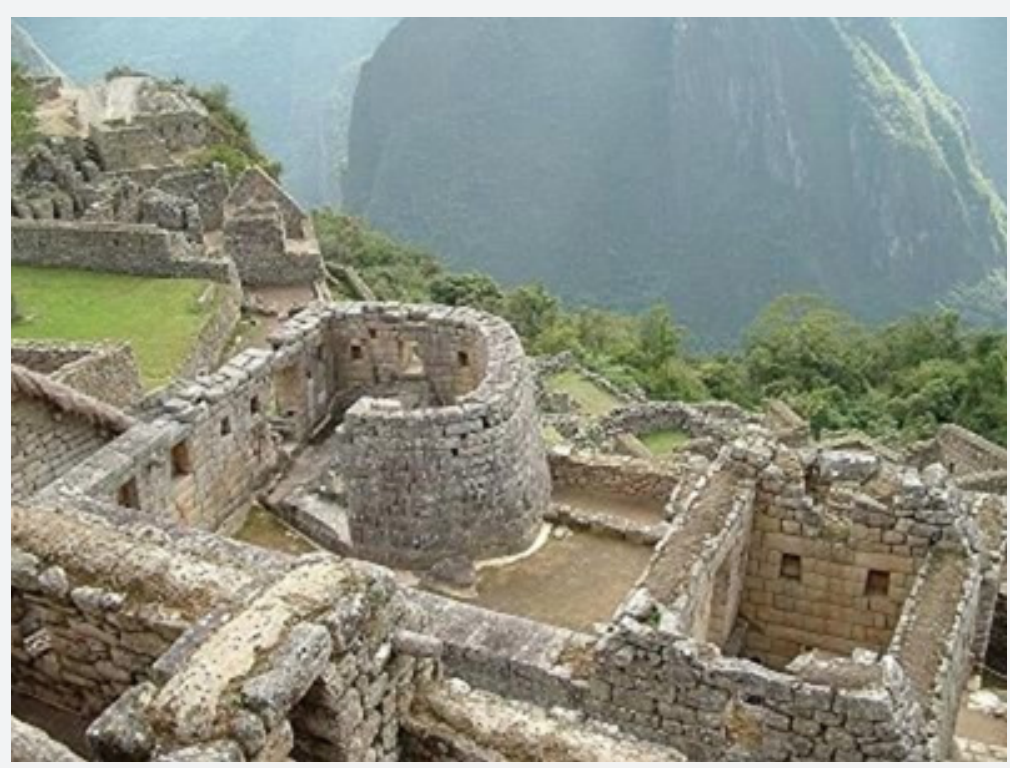

Figure 3: The Temple of The Sun, Photograph, Digital File.

The zenith passage was a way for the Incans to keep track of time. Only for a period of five days on either side of the zenith passage does the sun enter both windows at sunrise. Bingham noted in his journal that the Incas, this was also known as the
March and September equinoxes. According to his description of the equinox observations in Cusco, the zenith passage dates are around February 13-14 and October 30 [26] (Figure 4). The zenith and anti-zenith passages were just as important as the solstices and 
equinoxes. These dates resulting in a more natural set of seasons. It is possible that the Incas also based these passage dates to the beginning of planting season and the beginning of harvest season. Although it was previously believed that planting and harvesting times were based on the environment, recent research suggests that the Inca could have associated zenith and anti-zenith dates with agricultural pursuits [27]. Furthermore, due to the position of the Torreón in Machu Picchu, the Pleiades rise is close to that of the sun at the June solstice [28]. Similar to the zenith passage, the Pleiades indicates crop fertility and the forecasting of weather. The Incas determined this by watching when the sun reached above Huayna Picchu, the highest point in the sky.

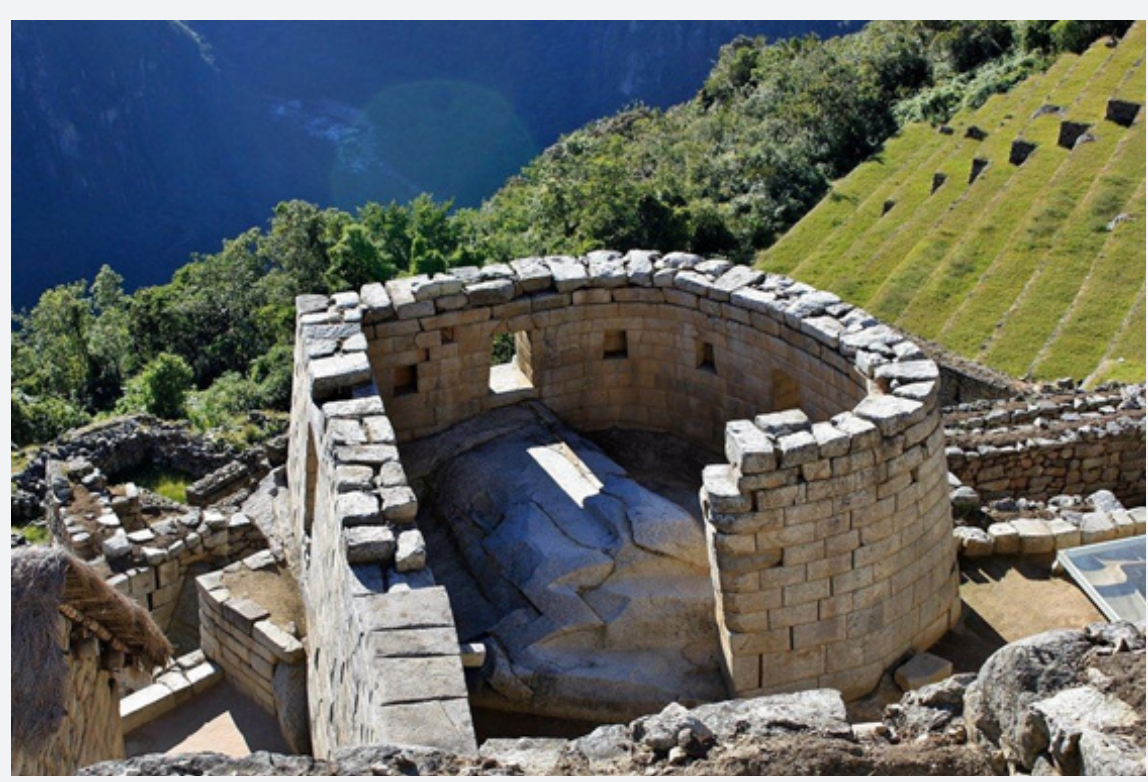

Figure 4: Machu Picchu Sun Temple, Photograph, March 18, 2013, Digital File.

Religion and worship provided an outlet for the Incas to better understand the world around them. Through their worship of the Sun god, Inti, they were not only able to gain a concept of time and place in the universe, but it also connected Machu Picchu and the whole civilization to the cosmos. Additionally, the Sun temple at Machu Picchu also played a crucial role in their success with agriculture-along with terraces.

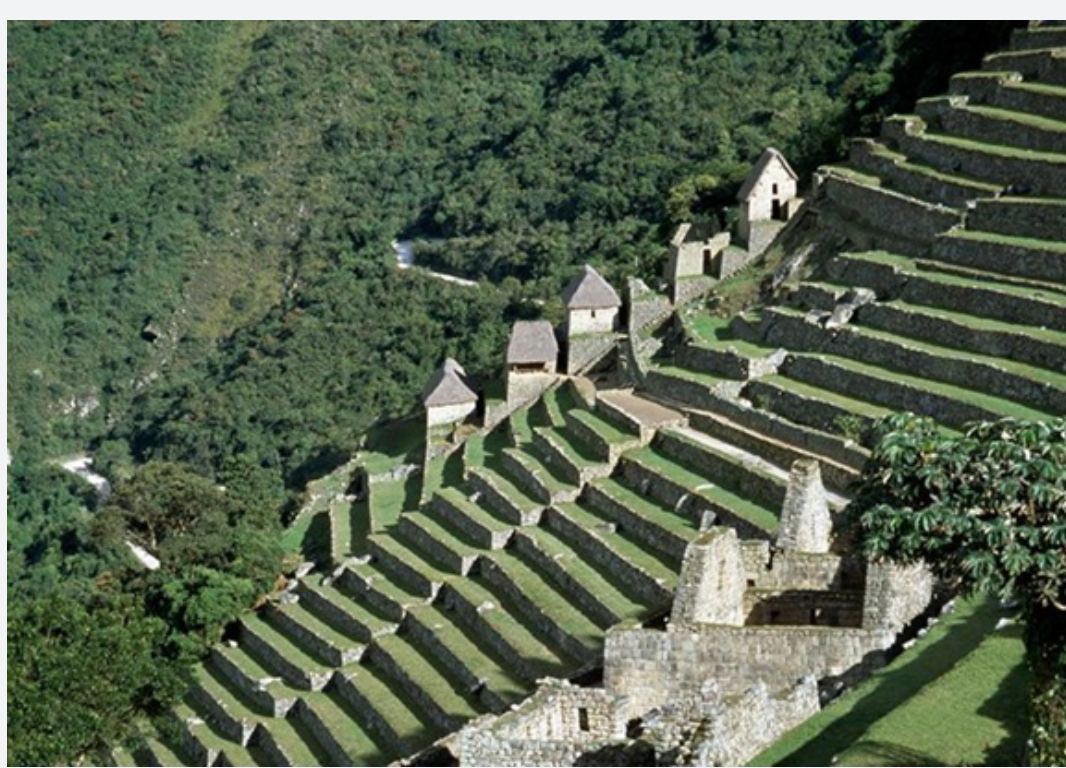

Figure 5: David Evans, Machu Picchu Terraces, Photograph, Digital File.

Since the majority of the Inca empire was built throughout the Andes Mountains, some of the tallest, starkest mountains in the world, the architecture of the civilization had to adapt to the environment. Simply possessing the land was not enough for the Inca; they physically reshaped it to fit their needs. The vast vertical terrain made farming difficult; the mountains lacked arable land. To solve that problem, the Inca seamlessly merged their architecture into the surrounding land and its specificities. A majority of the farming at Machu Picchu was done on man-made terraces [29]. Although prior civilizations had made small-scale terraces, no other group had approached it with the quality and quantity that the Inca did. Most of the terraces were found around royal private 
estates. This suggests that not only did the Inca find terraces to be a vital part of their lifestyle, but the terraces also acted as a symbol of their dominance throughout South America. Researchers estimate that at Machu Picchu there were up to 700 terraces operating at a time [30]. The terraces not only served as a way for the Inca to convert the mountain into food, but it also served as a symbol of the Inca's power to control basic food supplies and water (Figure 5).

The terraces at Machu Picchu were built in layers-- the bottom layer consisted of larger stones covered with loose gravel (Figure 6). The top layer was a mix of both sand and gravel packed tightly together [31]. Since the Inca had to build into the mountain at Machu Picchu, researchers suggest that the top layer of soil was probably moved from the more nutritious and fertile valley floor. Terraces also played a major role in Machu Picchu's longevity [32]. Due to the fluctuations in weather and heavy rainfall, Machu Picchu would have experienced frequent mudslides, landslides, erosion, and flooding if they did not have terraces and other ways to drain the excessive amount of water. Since agriculture made up a majority of the Inca economy, these natural disasters would have created a devastating decline of crop production as well as the empire's downfall. However, with time, the Incas figured out a way to combat this issue.

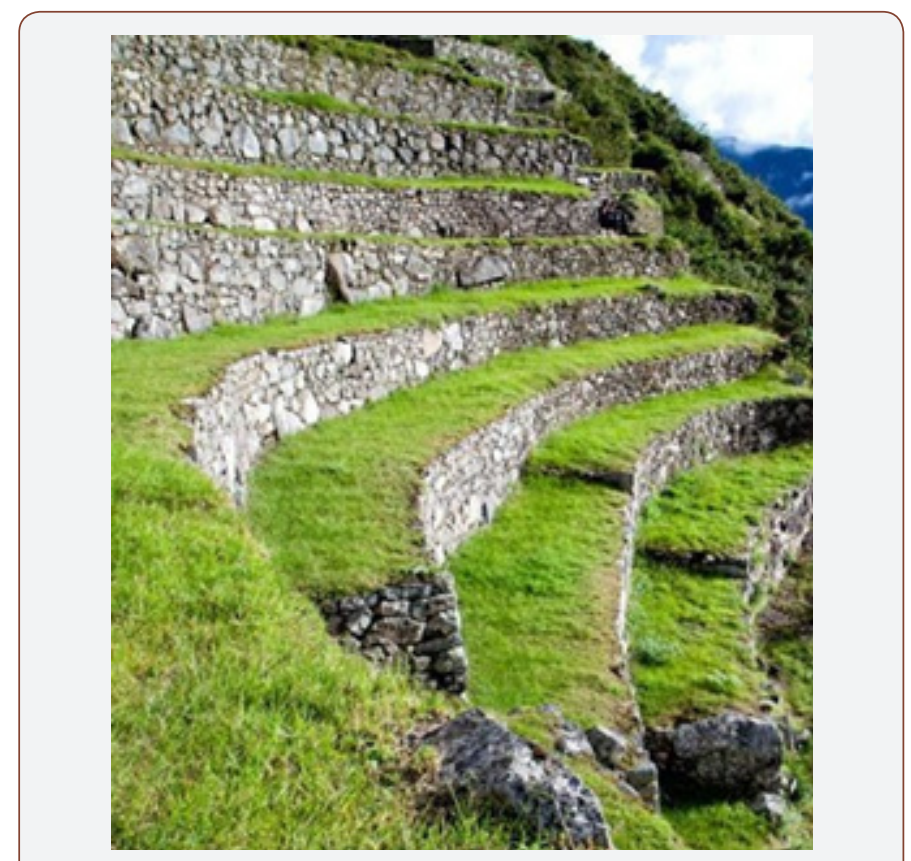

Figure 6: Terraces at Machu Picchu, Photograph, December 7, 2015, Digital File.

Archaeologist Ann Kendall began studying terraces in the Cusco region of Peru in 1968. Through her work at Machu Picchu, Kendall discovered that the terraces not only "leveled the planting area, but they also had several unexpected advantages" [33]. In a country as geographically diverse as Peru, the weather varies greatly throughout the different months. As they continued to develop and grow as a civilization, the Incas discovered innovative ways to ensure they had crops throughout the whole year-a vast network of storage facilities was developed against times of drought and disaster [34]. Although these storage facilities could store excess water and fresh crops for months on time, Kendall discovered that the terraces themselves were also extremely efficient at water control-draining ample amounts of water during the wet season, November and March, while also retaining the excess water and conserving it for the dry season, April to November.35 These terraces were a work of considerable engineering, built to ensure good drainage and soil fertility while also protecting the mountain itself from erosion and landslides.

In addition, Kendall also discovered that the mountains themselves also had properties that could regulate temperature. For example, as the sun hit the terrace walls during the day, the stone was able to retain this natural source of heat and slowly release it to the soil as the temperature plunged to at night. This kept the roots of the sensitive crops warm during frigid nights; it also elongated the growing season, allowing the Incas to use the terraces for longer periods of time [36]. In the 1400s, at the peak of the Inca empire, the system of terraces covered about a million hectares throughout Peru and fed the vast empire-with the terraces at Machu Picchu covering around 32,500 hectares [37]. Through the Incas' capability to "tame nature" [38], they were able to create agriculturally productive lands in even the most remote places-- converting the very rock of the mountain into food and transforming rainfall into nutrition.

Although the fall of the Inca empire was inevitable from the Spaniards due to their lack of exposure to foreign diseases and steal weapons, it was one of the most astonishing and sophisticated empires from the Ancient world. It still influences our world today, with millions of tourists visiting Machu Picchu every year. Machu Picchu stands as a physical symbol of the culture that created it. From its picturesque location in the rough terrain of the Andes Mountains to the quality of each perfectly cut stone, it truly is spectacular. It epitomizes the Inca Empires' success through its display of extraordinary craft and control over stone. They had a special relationship to stone, incorporating it into the landscapeblending in and blurring the line between natural and manmade. Another key defining characteristics of the Inca empire was their connection to the cosmos. Worship of the Sun god, Inti, provided them with an outlet to understand the world around them. Gathering their observations, the Inca were able to implicate an organized system of time into their lifestyle. This made their civilization flourish and prosper even more, with an increase in agriculture, due to the yearly "calendar" they followed, and also awareness of their surroundings.

However, it wasn't only their belief in the Sun god that made their agriculture techniques stand out from other civilizations of the time-ultimately, it came down to their ability to convert their surroundings into food. Machu Picchu's abundance in agricultural terraces, with around 700 operating at a time, was sufficient enough to feed the population. Due to the natural properties of the mountain itself and the water from the natural springs, it had the ability to be self-contained. The Incas had figured out a way to "tame nature", manipulating it to fit their needs. Perched above the Urubamba River valley in a narrow saddle between countless lush green mountains, Machu Picchu, a sublime stone citadel, is the perfect 
example of the perception of landscapes. As philosopher Immanuel Kant described in Mark Adams's book Turn Right at Machu Picchu, sublime means, "something limitless, an aesthetically pleasing entity so huge that it made the perceiver's head hurt. Machu Picchu isn't just beautiful, it's sublime" [39].

\section{References}

1. Johan Reinhard, Machu Picchu: Exploring an Ancient Sacred Center (World Heritage and Monuments), ( $4^{\text {th }}$ edn). np: Cotsen Institute of Archaeology Press, 12.

2. (2009) Machu Picchu discovered by American archeologist, HISTORY.

3. Reinhard, Machu Picchu,13.

4. Reinhard, Machu Picchu,12.

5. Bingham, Lost City, 203.

6. Bingham, Lost City, 203

7. Bingham, Lost City, 204.

8. Bingham, Lost City, 204.

9. Rebecca Firestone (2016) Rock Whisperers: The Subtle Power of Incan Masonry, The Architects' Take (blog).

10. Helmut Tributsch (2017) On the reddish, glittery mud the Inca used for perfecting their stone masonry.

11. Mark Cartwright (2014) Inca Architecture, Ancient History Encyclopedia.

12. Tributsch, On the reddish.

13. Bingham, Lost City, 205.

14. Tributsch, On the reddish,

15. Mark Adams (2011) Turn Right at Machu Picchu: Rediscovering the Lost City One Step at a Time New York, USA.

16. A Cartwright, Inca Architecture, Ancient History Encyclopedia.
17. Bingham, Lost City, 204.

18. Katharina Schreiber, David SP Dearborn (1986) Here Comes the Sun: The Cuzco-Machu Picchu Connection.

19. Mark Cartwright (2014) Inti, Ancient History Encyclopedia

20. Schreiber and Dearborn, Here Comes, 15.

21. Mark Cartwright (2016) Inca Religion, Ancient History Encyclopedia.

22. Hiram Bingham (1948), Lost City of the Incas.

23. Bingham, Lost City, 206.

24. Schreiber and Dearborn, Here Comes, 17.

25. Schreiber and Dearborn, Here Comes, 25.

26. Schreiber and Dearborn, Here Comes, 32.

27. Schreiber and Dearborn, Here Comes, 35.

28. Reinhard, Machu Picchu, 76.

29. Stella E Nair (1996) Inca Architecture and the Conquest of the Countryside.

30. (2009) A Marvel of Inca Engineering, PBS.

31. Richard L, Burger, Lucy C, Salazar, Machu Picchu: Unveiling the Mystery of the Incas (New Haven \& London: Yale University Press, USA.

32. A Marvel, PBS.

33. Cynthia Graber (2019) Farming Like the Incas.

34. Mark Cartwright (2015) Inca Food \& Agriculture, Ancient History Encyclopedia.

35. Graber, Farming Like.

36. Graber, Farming Like.

37. Burger and Salazar, Machu Picchu, 74.

38. Adams, Turn Right, 188.

39. Adams, Turn Right, 190. 